\title{
THE EFFECT OF SOME BIOTIC AND ABIOTIC FACTORS ON SEASONAL FLUCTUATIONS OF HELICOVERPA ARMIGERA (HUB.)
}

\author{
RAGAB, M.G., A. A.A. EL-SAYED and M. A. NADA
}

Plant Protection Research Institute, ARC, Dokki Giza, Egypt

(Manuscript received 1 December 2013)

\begin{abstract}
Studies were conducted to ascertain the effect of biotic and abiotic environmental factors on the seasonal population fluctuation of $H$. armigera and relationships of its eggs and larvae on cotton variety (Giza 86) during four successive cotton seasons (from 2005 to 2008) that extended from the first week of April to the last week of September at Zefta district, in Gharbia Governorate, Egypt.

Results showed that the $H$. armigera moths harboured to the cotton fields, as soon as, the cotton seedlings appeared. The moths have been existed in 4-5 main peaks with few minor peaks during the experimental seasons. The fruit cotton structures, (Receptors) began to emerge at the first half of May and continued to the end of the study period. Also, one to three main peaks of $H$. armigera eggs and larvae were existed per season. Statistically, multiple regression were judged by (full model) to predict the relationship between the dependent variables (eggs or larvae of $A B W$ ) that affected by four or five independent variables, lunar days, percentages of moon light, moths caught in light trap, eggs and cotton receptors, during 2005 to 2008 cotton seasons. The Analysis of Variance showed highly significant regression values between the expected eggs, larvae \& trapped moths and lunar days, percent moonlight $\&$ the cotton receptors for the four experimental seasons. The expected eggs $=(4.470)+(-0.121 *$ lunar days $)+(0.151 *$ percent moonlight $)+(1.023 *$ moths $)+$ $(1.136 *$ receptors $)$. The expected larvae $=(2.482)+(0.003 *$ lunar days $)+(-0.060 *$ percent moonlight $)+(-0.004 *$ moths $)+$ $\left(0.342^{*}\right.$ eggs $)+(-0.021 *$ receptors $)$ as average for the four seasons. The fit regression equation was represented with the $r^{2}$ values which were 0.554 and $0.949 \&$ the total effect 55.41 and \% 94.9 and sum of the deviations square were 3339.21 and 44.57, respectively. Therefore, the previous four or five independent factors can be used to forecast population of ABW eggs or larvae before appearing of its peaks on cotton plants by enough periods to organize control measures and apply the recommended pesticides when really needed.

Key words: Helicoverpa armigera (Hub.), American bollworm (ABW), Seasonal fluctuation \& biotic and abiotic environmental factors.
\end{abstract}




\section{INTRODUCTION}

Cotton plays a vital role in economy of Egypt. Gossypium barbadens (L.) resembled other field crops to be attacked by a range of insect pests during its growing season. In Egypt, Helicoverpa armigera (Hub.) is polyphagous and causes substantial losses to various crops. In case of cotton, they attack flowers, squares and bolls.

Helicoverpa armigera $(\mathrm{Hb}$.$) is one of the most important economic insect pests$ of cotton in many parts of the world .The eggs and /or larvae of this polyphagous pest were recorded on more than 60 plant species belonging to 47 families including maize, sorghum, tomato, Lucerne, tobacco, cotton clover and cowpea (Fitt, 1989). Egg numbers of $H$. armigera were significantly higher on sunflower, okra and tomato than cotton, but larval numbers were not significantly differed from cotton at comparable time (El-Sayed, et al., 2009). Direct damage to flowering and fruiting structures by larvae and extensive periodic insecticide applications resulted in low yield and high control costs. Many investigations suggested that generation's cycles of American bollworm (ABW) are synchronized with lunar cycles, independently of host plant phenology, climatic factors and accumulated heat units (Legaspi et al., 1989, Zalucki et al., 1994). An inverse relationship has been established between light trap catches of ABW moths and moon light with the highest trap catch occurring during new moon and lowest during full moon (Nemec, 1971, Bowden, 1973, and Youssef \& Ismail, 1999). Sadanny et al. (1999) reported that mean air temperature and relative humidity were positively correlated with infestation, while Ragab (2009) reported that there were conspicuous positive correlation between the numbers of ABW moths and thermal heat units expressed as day-degrees accumulation. Ibrahim et al. (1994), Nada et al. (2004), Nada \& Ragab (2010) and Nada et al. (2012) studied the relationship between population fluctuations of $H$. armigera as an important cotton pest and the physical environmental factors in Egypt. Also, Bilal Saeed Khan et al. (2003), K uldeep Singh et al. (2011) \& Khalid Zafar et al. (2013 determined the effect of different weather factors on egg count and larval population of $\mathrm{H}$. armigera in sunflower and different nectary and non-nectary cotton varieties. Studies of abiotic factors against the infestation fluctuation of American bollworm revealed that maximum temperature showed significant and positive correlation $r$-value with the egg counts, whereas, relative humidity had negative and significant correlation with the eggs count with $r$-value. 
More detailed knowledge of the seasonal activities of this insect is necessary in order to organize control measures and the application of recommended insecticides when really needed.

\section{The main objective of the present study was:}

1- Monitoring of cotton bollworm moths in light trap to study its seasonal activity.

2- Assay the effect of some weather factors on cotton bollworm population and study the relationship between moth catches of cotton bollworm ,the numbers of laid eggs and larvae with these factors and the cotton receptors (fruit structures :squares, bloom and bolls) during four cotton seasons (2005 - 2008).

\section{MATERIALS AND METHODS}

The present study was carried out at a private farm located in a Village at Kafr El-Guindy, Zefta district, Gharbia Governorate, within an assemblies of cotton, about 40 - 50 feddan, during four successive cotton seasons (from 2005 to 2008). The fields were sown by the Egyptian cotton, Gossypium barbadense (L.) variety Giza 86 during 2005 and 2008 cotton seasons. Cotton seeds were cultivated at dates ranged between the second half of March to the first week of May. The experimental area was subjected to normal agricultural practices at critical growth stages of cotton crop. Procedures of cotton pest control in the experimental area were applied according to programs of the Ministry of Agriculture. Cotton fields were surrounded by clover, wheat and vegetables fields during the winter seasons prior to the cotton, and with maize and vegetables during the summer seasons.

One light trap, modified by Hosny (1958), was set on the roof of a village house six meters above the ground near the cotton experimental fields. The light trap catches were collected weekly and sorted to species. $H$. armigera adults were especially collected and inspected .One feddan $\left(4200 \mathrm{~m}^{2}\right)$ was selected as the experimental area (sown at the third week of March). A stratified random sampling technique was used (Gomez and Gomez, 1983). Twenty five meters (50 hills $=100$ plants) of one meter row each of cotton plants ( 2 hills /meter) were for counting eggs and larvae, (at the upper terminal of the cotton plants, $20 \mathrm{~cm}$.). All fruit structures (squares, bloom and bolls) on the same plants in one meter of row samples were examined at weekly intervals throughout the growing seasons. The total receptors were summation of the squares, bloom and bolls. The lunar days were calculated from the beginning lunar year. The daily percentages of visible moonlight cycle were 
obtained from the site (WWW.Calendar-365.com). To determine the seasonal population fluctuations of $H$. armigera adults, the collected data were represented graphically. It was plotted according to Gregorian months. The impact of six variables were converted every three days and subjected to statistical analysis to determine the relationship between $H$. armigera eggs and larvae and four or five environmental factors abiotic( lunar days $\&$ moonlight) and biotic factors ( collected moths, counted eggs, larvae \& receptors).

\section{RESULTS AND DISCUSSION}

Field observations proved that, as soon as, the cotton seedlings appeared in the cotton fields, which are sown at the third week of March, the $H$. armigera moths harboured to the cotton fields as an important host in this time. The ABW moths' occurrence in the light trap began to be recorded at the first week of April. The actual number of $H$. armigera, represented in the different stages, moths, eggs and larvae, at the experimental area in the four seasons, are tabulated in Tables (1-6) and graphically illustrated in Figs. (1-6).

\section{a) Seasonal fluctuations of $\boldsymbol{H}$. armigera :}

i) Seasonal fluctuation of moths, data in Table (1) Figs (1-4) demonstrated that 4-5 main peaks of $\mathrm{H}$. armigera moths which occurred during the investigated seasons, with few minor peaks. In the first season (2005), four main moth peaks were recorded. Moths recorded in the trap at the $23^{\text {rd }}$ of April and increased gradually till the $11^{\text {th }}$ of May, the first moth peak. The three other moth peaks were recorded at the $13^{\text {th }}$ of Jun, the $7^{\text {th }}$ of July, and the $9^{\text {th }}$ of August. The largest moth peak in trap was recorded in the fourth peak at the $9^{\text {th }}$ of August and the lowest was in the first moth peak at the $11^{\text {th }}$ of May, Table (1) and Fig. (1). Four main moth peaks were recorded similar to the previous season In the second season (2006), where the first record of moths were at the $17^{\text {th }}$ of April and increased gradually till the $29^{\text {th }}$ of May(the first peak). The three other moth peaks were at the $28^{\text {th }}$ of Jun, the $3^{\text {rd }}$ of Aug. and $30^{\text {th }}$ of August, respectively. The lowest number of trapped moths were at the $29^{\text {th }}$ of May, while the largest number were recorded at the fourth peak (30th of August) Fig. (2).The moth peaks recorded in the third season (2007), was actually similar to the two previous seasons, whereas in the fourth season (2008) moths recorded five peaks differently from the previous three seasons Figs. (4).

Moth peaks were occurred at different times throughout the investigated cotton seasons (2005-2008). The differences in days between the peaks occurrence was 18 days, 9 days and 9 days among 2005 \&2006, 2006 \& 2007 and 2007 \& 2008, 
respectively. The same trend was found in the second, third and fourth peaks of moths during the four experimental seasons Table (1). These differences in days between the peaks in the different seasons attributed to the lunar cycles as an abiotic factor. These results agreement with Nada, et al. (2012) that found the highest number of the trapped moths was during the darkness period, no moon, and the lowest number of moths was caught during the full moon period.

ii)Eggs occurrence, data in Table (2) and Figs (1 -4) are demonstrated to 1-3 main egg peaks of $H$. armigera that occurred during the four cotton seasons, by two egg peaks, a peak, two peaks and three peaks in 2005,2006,2007\&2008, respectively. The fruit cotton structures (squares) appeared at May, $20^{\text {th }}$ in the two seasons of 2005 and 2006, while at $8^{\text {th }}$ May, in 2007 and11 ${ }^{\text {th }}$ May in 2008 cotton seasons that followed by the other fruits (blooms and bolls) to the end of the study period. The present observations recorded that The ABW eggs occurrence at the selected cotton plant area (6 - 9 days) earlier than the receptors appearance during the investigation periods, the only exception occurred in 2007 season where the receptors emerged earlier by 3days. The largest number of eggs was recorded at the second, first, first and second peak during June, $22^{\text {nd }}$, July, $7^{\text {th }}$, Jun, $25^{\text {th }}$ and July $13^{\text {th }}$, , during the four cotton seasons, respectively. The differences in the eggs occurrences might be attributed to the nature of the receptors growth. Receptors occurrences on the cotton plants are almost located at close dates, this is because the mechanism of plant growth depends heavily on the thermal requirements and the length of the day. While, egg occurrences located almost at the dates far between, because the egglaying mechanism relies mainly on moths, which in turn depends on the environmental factors as the moon light which consequently determined by the lunar calendar.

iii) Larval occurrence, Table (3) illustrated in Figs. (1 -4) recorded that the ABW larvae had 1-2 main peaks in the investigated period. In the first season (2005), the larvae occurred in a peak and recorded on cotton plants at the $14^{\text {th }}$ of May, legitimate biologically after eggs laying by 6 days, and increased gradually till the peak of larvae at the $22^{\text {nd }}$ of June. Two peaks, one peak and two peaks were occurred in the second, the third and the fourth seasons. The larval occurrence during 2006 season was at the $28^{\text {th }}$ of June and at the $28^{\text {th }}$ of July.

Numbers of eggs and larvae that recorded in the study periods were inconsistent with numbers of moths caught at the same periods (May, Jun, July and the first half of August). The numbers of eggs are not commensurate with the moth 
population in these periods, where the moth population is much higher than the number of eggs and larvae. Ragab, 2004 and Ragab et al., 2009 recorded some common insect predators as Coccinelids spp., Paederus alfierii, chrysoperla carnea, Orius spp. and other predators that attack cotton pests at cotton fields in this period, which leads to predation the eggs and larvae. Salem et al., 2004 and Ragab, 2009 reported that many hosts of this pest located in the summer planting season as maize, sunflower and vegetables etc. The moths move to the previous surrounded suitable hosts, and these hosts have produced its fruits that are favorites to insect for eggs lying. Thus, this is other cause to inconsistent between the moths, eggs and larvae on cotton fields.

b) Effect of some biotic and abiotic environmental factors the on population density of $\boldsymbol{H}$. armigera:

i)Relationships between eggs and the four independent factors, present results indicated that fit regression equation between the dependent variable (eggs) and the independent variables, lunar days, percentages of moon light, moths caught in light trap and receptors (squares, bloom and green cotton bolls) (Table 4 and Fig.5). Variables was represented in the coefficient of determination $r^{2}$ values, total effect of five independent variables and sum of deviations square of the expected than observed population.

In 2005 cotton season, analysis of variance showed a highly significant to the regression and independent variables lunar days. The percentage of moon light, moths and receptors were insignificant. The $r^{2}$ value was 0.350 and the total effect of independent variables on the dependent variables eggs was $358 \%$. The expected population of larvae does not coincide with fluctuation of the observed one (Table $4 \&$ Fig.5). Sum of the deviations square was 5100.23. In 2006 cotton season, the analysis of variance showed highly significant regression between caught moths and the independent variables. The other independent variables (the percentage of moon light, lunar days and receptors) were insignificant. The $r^{2}$ value was 0.480 and the total effect was $48.0 \%$. The expected population of eggs dose not coincides with fluctuation of the observed one (Fig. 5). Sum of the deviations square of the expected than observed population were 3523.4. The same trend was found in the two seasons of 2007 and 2008, where, the $r^{2}$ values were 0.708 and 0.514 and the total effect was 70.75 and $51.37 \%$, also, sum of deviations square were 9285.2 and 2924.05 (Table $6)$. 
In 2007 cotton season, the representing high deviation might be due to the occurrence of eggs population at more than one peak.

The multiple regression equation (full model) between the dependant and independent variables for average of 2005-2008 cotton seasons was the expected population of $H$. armigera eggs $=(4.470)+(-0.121 *$ lunar days $) 0.151 *$ percent moonlight $)+(-1.023 *$ moths $)+(1.136 *$ receptors $)$. The fit regression equation was represented in the $r^{2}$ value which was 0.5541 , total effect $55.41 \%$ and sum of deviations square was 3339.21.

ii)Relationship between larvae and five independent factors, multiple regression (full model) were subjected between dependent variable (larvae) and five independent variables, lunar days, percentages of moon light, Moths in trap, eggs and receptors (squares, bloom and green cotton bolls) during 2005 -2008 cotton seasons in Tables (5\& 6) and Fig. (6). Also, fit regression equation between the dependant and independent variables was represented in the coefficient of determination $r^{2}$ values and total effect of five independent variables.

In 2005 cotton season, the analysis of variance of the multiple regressions showed a highly significant relation with the four independent variables, lunar days, percentage light, eggs and receptors, and an insignificant relation with moths. The $r^{2}$ value was 0.939 and the total effect of independent variables on the dependent variables larvae was $93.9 \%$. The expected population of larvae coincides with fluctuation of the observed one (Fig. 6). Sum of deviations square of the expected than observed population were 50.8 Table (6). In 2006 cotton season, the analysis of variance of the multiple regressions showed a highly significant with the four independent variables, lunar days, moths, egg and receptors and an insignificant relation with the percentage of light. The $r^{2}$ value was 0.824 and the total effect of independent variables on the dependent variables larvae was $82.4 \%$. The expected population of larvae coincides with the fluctuation of the observed one Fig. (6). Sum of the deviations square of the expected than observed population were 302.7. The same trend was found in the two other seasons 2007 and 2008, where, the $r^{2}$ values were 0.8401 and 0.8334 and the total effect was 84.01 and $83.34 \%$, also, sum of deviations square was 204.9 and 88.0.

The expected population of H. armigera larvae in 2006 cotton season coincides with the observed peak which occurred in 2005 cotton season where the lowest deviation 50.8 occurred in 2005, in contrary the highest deviation 302.7 in 2006. The highest deviation may be due to the fluctuation of larval population at more 
than peak. $2007 \& 2008$ cotton seasons deviation values came in between the previous values (Table 6). The multiple regression equation (full model) between the dependant and independent variables was the expected population of $\mathrm{H}$. armigera larvae $=(2.482)+(0.003 *$ lunar days $)+(-0.060 *$ percent moonlight $)+(-$ $0.004 *$ moths $)+(0.342 *$ eggs $)+(-0.021 *$ receptors $)$ as an average for four seasons. The fit regression equation was represented in the $r^{2}$ value which was 0.949 , total effect $94.9 \%$ and sum of deviations square was 44.57 Table (6).

The accuracy of the multiple regression equation for larvae was more accurate than the same equation with eggs. Therefore, the five independent variables, lunar days, percentages of moon light, moths in trap, eggs and receptors (squares, bloom and green cotton bolls) can be used to forecast population of ABW larvae before appearing of its peaks with enough periods for control of this pest.

Table 1. The occurrence of Helicoverpa armigera moths in cotton season of (2005-2008).

\begin{tabular}{|c|c|c|c|c|c|c|c|}
\hline Phenomenon & 2005 & 2006 & $\begin{array}{c}* * * \text { The } \\
\text { different } \\
\text { between } \\
2005- \\
2006\end{array}$ & 2007 & $\begin{array}{c}\text { The } \\
\text { different } \\
\text { between } \\
2006- \\
2007\end{array}$ & 2008 & $\begin{array}{c}\text { The } \\
\text { different } \\
\text { between } \\
2007- \\
2008\end{array}$ \\
\hline Recorded at & *April,23 & April,17 & 6 & April,2 & 15 & April,2 & 0 \\
\hline peaks 1 & **May, 11 & May,29 & 18 & May,20 & 9 & May, 11 & 9 \\
\hline 2 & Jun,13 & Jun,28 & 15 & Jun,19 & 9 & Jun,7 & 12 \\
\hline 3 & July,7 & Augu.,3 & 27 & July,16 & 18 & July,7 & 9 \\
\hline 4 & Aug.,7 & Augu.,30 & 23 & Aug.,15 & 15 & Aug.,3 & 12 \\
\hline 5 & - & - & - & - & - & Sept.,2 & \\
\hline Largest peak & Aug.,9 & Aug.,30 & -21 & Aug.,15 & 15 & Aug.,3 & -12 \\
\hline Lowest peak & May,11 & May,29 & 0 & Sept.,29 & 0 & Sept.,29 & 0 \\
\hline
\end{tabular}



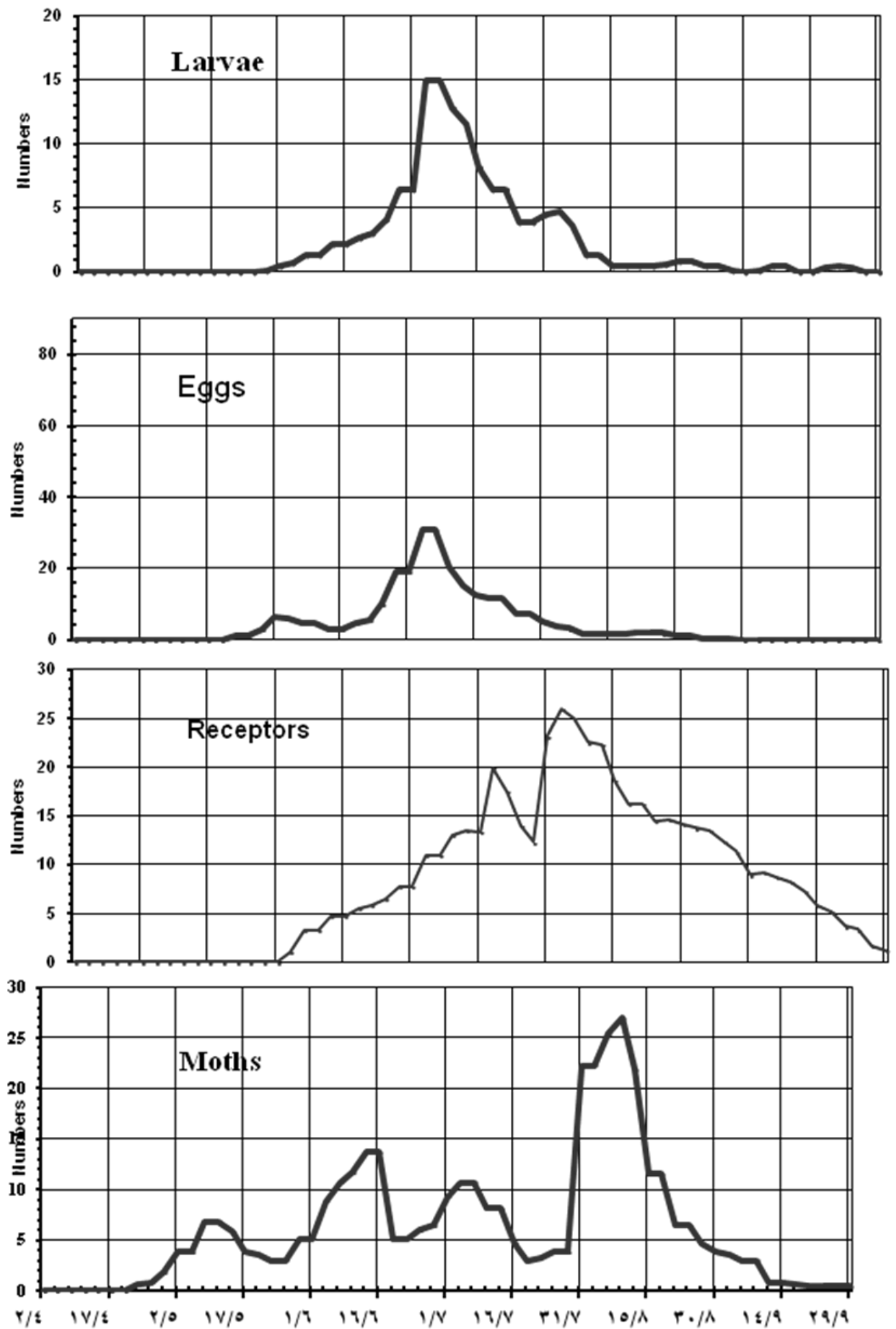

Figure(1): Peaks occurrences of different stages of Helicoverpa armigera , moths, eggs, larvae, and cotton receptors during 2005 cotton season 

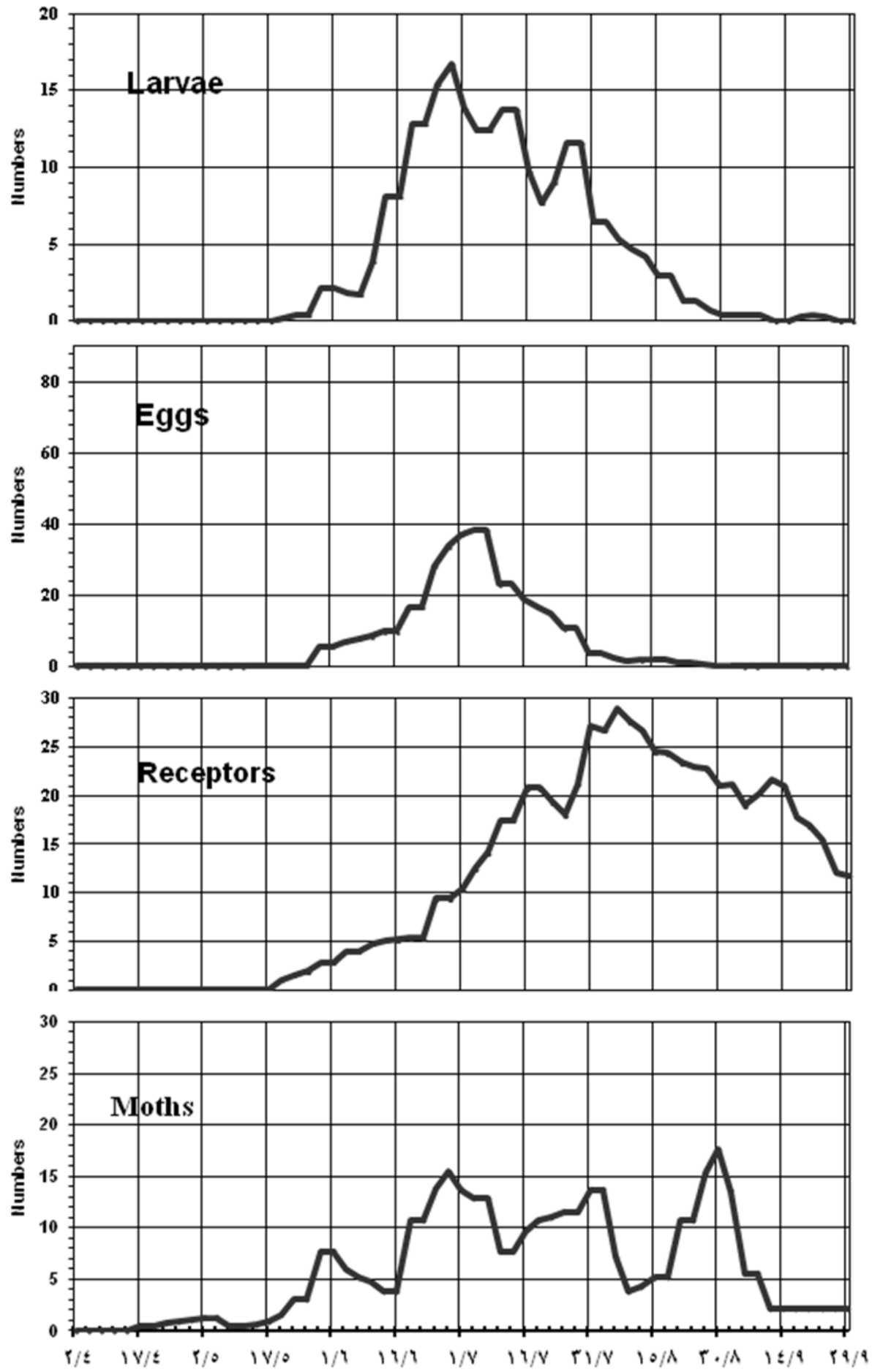

Figure(2): Peaks occurrences of different stages of Helicoverpa armigera , moths, eggs, larvae, and cotton receptors during 2006 cotton season 

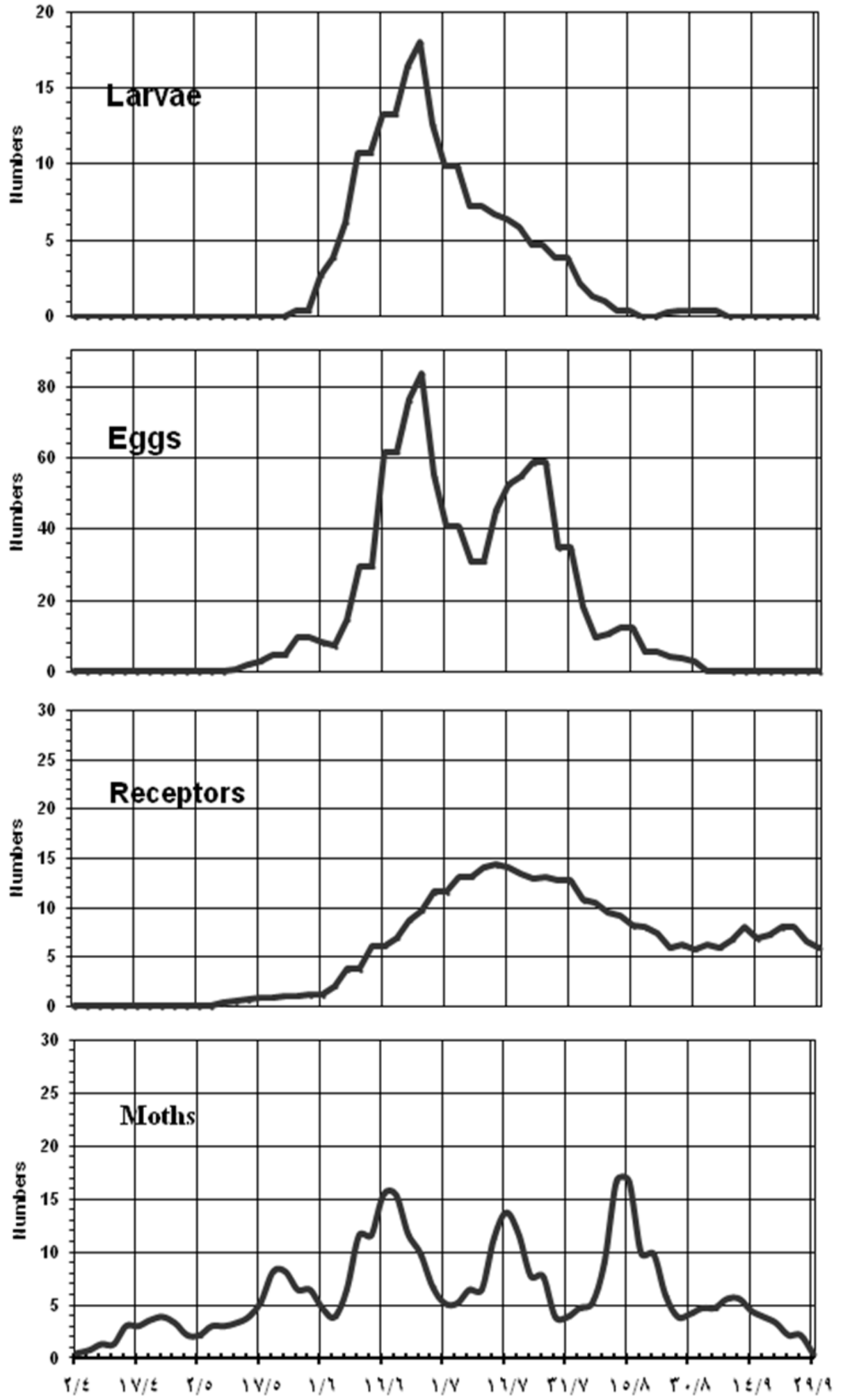

Figure(3): Peaks occurrences of different stages of Helicoverpa armigera , moths, eggs, larvae, and cotton receptors during 2007 cotton season 
Table 2. The occurrence of Helicoverpa armigera eggs in cotton season of (2005-2008).

\begin{tabular}{|c|c|c|c|c|c|c|c|}
\hline Phenomenon & 2005 & 2006 & $\begin{array}{c}* * * \text { The } \\
\text { difference } \\
\text { between } \\
2005-2006\end{array}$ & 2007 & $\begin{array}{c}\text { The } \\
\text { difference } \\
\text { between } \\
2006-2007\end{array}$ & 2008 & $\begin{array}{c}\text { The } \\
\text { difference } \\
\text { between } \\
2007-2008\end{array}$ \\
\hline $\begin{array}{c}\text { Receptors } \\
\text { apeared at }\end{array}$ & May,20 & May,20 & 0 & May,8 & 12 & May,11 & -3 \\
\hline Egg recorded & $*$ May,8 & May,14 & -6 & May,11 & 3 & May,20 & -9 \\
\hline $\begin{array}{c}\text { Egg peaks } \\
1\end{array}$ & $* *$ May,17 & July,7 & -51 & Jun,25 & 12 & Jun,16 & 9 \\
\hline 2 & Jun,22 & - & - & July,25 & - & July,13 & 12 \\
\hline 3 & - & - & - & - & - & Aug.,9 & - \\
\hline Largest peak & Jun,22 & July,7 & -15 & Jun, 25 & 12 & July,13 & -18 \\
\hline Lowest peak & May,17 & & & July,25 & 12 & Aug.,9 & 18 \\
\hline
\end{tabular}

$*=$ Eggs recorded at.., $* *=$ peaks occurred at.., $* * *=$ Population occurred early $(+)$ or late $(-)$ than the previous season.

Table 3. The occurrence of Helicoverpa armigera larvae in cotton season of (2005-2008).

\begin{tabular}{|c|c|c|c|c|c|c|c|}
\hline $\begin{array}{c}\text { The } \\
\text { Phenomenon }\end{array}$ & 2005 & 2006 & $\begin{array}{c}* * * \text { The } \\
\text { difference } \\
\text { between } \\
2005- \\
2006 \\
\end{array}$ & 2007 & $\begin{array}{c}\text { The } \\
\text { difference } \\
\text { between } \\
2006- \\
2007\end{array}$ & 2008 & $\begin{array}{c}\text { The } \\
\text { difference } \\
\text { between } \\
2007- \\
2008\end{array}$ \\
\hline $\begin{array}{l}\text { Receptors } \\
\text { apeared at }\end{array}$ & May,20 & May, 20 & 0 & May, 8 & 12 & May, 11 & -3 \\
\hline $\begin{array}{r}\text { larvae } \\
\text { recorded at }\end{array}$ & *May, 14 & May,20 & -6 & May,26 & -6 & Jun,4 & -11 \\
\hline $\begin{array}{r}\text { larvae peaks } \\
1 \\
\end{array}$ & **Jun,22 & Jun,28 & -6 & Jun,25 & 3 & July,7 & -12 \\
\hline 2 & - & July,28 & - & - & - & July,28 & - \\
\hline Largest peak & Jun, 22 & Jun,28 & 6 & Jun,25 & 3 & July,7 & -3 \\
\hline Lowest peak & 0 & July,28 & 0 & 0 & & July, 28 & \\
\hline
\end{tabular}


Tables 4. Briefly analysis Varriance of multiple reggression (full model) and Regression equation parameter of predicted dependant variable (eggs) for four independent variables during 2005 -2008 cotton season

\begin{tabular}{|c|c|c|c|c|c|c|c|c|}
\hline \multicolumn{7}{|c|}{2005} & \multirow{3}{*}{$r^{2}$} & \multirow{3}{*}{$\begin{array}{l}\text { Total effect } \\
\text { of } \\
\text { independent } \\
\text { variables }\end{array}$} \\
\hline \multicolumn{3}{|c|}{ Analysis Varriance } & \multicolumn{4}{|c|}{$\begin{array}{l}\text { Regression equation parameters of predictrd } \\
\text { larvae }\end{array}$} & & \\
\hline Source & $\mathrm{F}$ & $P$ & parameters & Coef. & $\begin{array}{c}\text { Std } \\
\text { Error }\end{array}$ & $\mathrm{P}$ & & \\
\hline Regression & 5.4 & $0.0015 *$ & Intercept & 21.781 & 5.416 & $\begin{array}{l}.0002 \\
* * *\end{array}$ & \multirow{5}{*}{0.350} & \multirow{5}{*}{$35.00 \%$} \\
\hline lunar dayes & 20.3 & $\begin{array}{c}0.0001 \\
* * *\end{array}$ & lunar dayes & -0.112 & 0.026 & $\begin{array}{c}.0001 \\
* * * \\
\end{array}$ & & \\
\hline $\begin{array}{l}\text { Percent } \\
\text { LIGHT }\end{array}$ & 1.0 & $\begin{array}{c}0.3203 \\
\mathrm{~ns}\end{array}$ & $\begin{array}{l}\text { Percent } \\
\text { LIGHT }\end{array}$ & 0.032 & 0.032 & 0.06518 & & \\
\hline Moths & 0.1 & $\begin{array}{c}0.7062 \\
\mathrm{~ns}\end{array}$ & Moths & 0.046 & 0.179 & $\begin{array}{l}.7968 \\
\text { ns }\end{array}$ & & \\
\hline $\operatorname{Rec}$ & 0.1 & $\begin{array}{c}0.8101 \\
n s\end{array}$ & $\operatorname{Rec}$ & -0.406 & 0.222 & $.8101 \mathrm{~ns}$ & & \\
\hline \multicolumn{7}{|c|}{2006} & \multirow{6}{*}{0.480} & \multirow{6}{*}{$48.00 \%$} \\
\hline Regression & 12.9 & .0000 & Intercept & -2.228 & 4.814 & $.0170 *$ & & \\
\hline lunar dayes & 0.2 & $.6892 \mathrm{~ns}$ & lunar dayes & 0.002 & 0.038 & $.9581 \mathrm{~ns}$ & & \\
\hline $\begin{array}{c}\text { Percent } \\
\text { LIGHT }\end{array}$ & 0.1 & .8108 ns & $\begin{array}{c}\text { Percent } \\
\text { LIGHT }\end{array}$ & 0.055 & 0.031 & $.0788 \mathrm{~ns}$ & & \\
\hline Moths & 48.2 & .0000 & Moths & 1.762 & 0.250 & .0000 & & \\
\hline $\operatorname{Rec}$ & 3.3 & .0727 ns & $\operatorname{Rec}$ & -0.406 & 0.222 & $.0727 \mathrm{~ns}$ & & \\
\hline \multicolumn{7}{|c|}{2007} & \multirow{6}{*}{0.708} & \multirow{6}{*}{$70.75 \%$} \\
\hline Regression & 26.6 & $\begin{array}{r}.0000 \\
* * * \\
\end{array}$ & Intercept & 31.792 & 12.815 & $.0170 *$ & & \\
\hline lunar dayes & 11.6 & .0014 & lunar dayes & -0.292 & 0.054 & $\begin{array}{l}.0000 \\
* * *\end{array}$ & & \\
\hline $\begin{array}{l}\text { Percent } \\
\text { LIGHT }\end{array}$ & 3.2 & .0795 ns & $\begin{array}{l}\text { Percent } \\
\text { LIGHT }\end{array}$ & 0.009 & 0.073 & .9032 ns & & \\
\hline Moths & 37.0 & $\begin{array}{l}.0000 \\
* * * \\
\end{array}$ & Moths & 1.598 & 0.696 & $.0265 *$ & & \\
\hline $\operatorname{Rec}$ & 54.6 & .0000 & $\operatorname{Rec}$ & 4.047 & 0.548 & $\begin{array}{ll}.0000 \\
* * * \\
\end{array}$ & & \\
\hline \multicolumn{7}{|c|}{2008} & \multirow{6}{*}{0.514} & \multirow{6}{*}{$51.37 \%$} \\
\hline Regression & 11.4 & $\begin{array}{l}.0000 \\
* * * \\
\end{array}$ & Intercept & 6.351 & 7.864 & $.4238 \mathrm{~ns}$ & & \\
\hline lunar dayes & 4.1 & $.0490 *$ & lunar dayes & -0.094 & 0.034 & $\begin{array}{ll}.0079 \\
* * \\
\end{array}$ & & \\
\hline $\begin{array}{l}\text { Percent } \\
\text { LIGHT }\end{array}$ & 0.4 & $.5278 \mathrm{~ns}$ & $\begin{array}{l}\text { Percent } \\
\text { LIGHT }\end{array}$ & 0.061 & 0.037 & $.1029 \mathrm{~ns}$ & & \\
\hline Moths & 23.4 & $\begin{array}{l}.0000 \\
* * *\end{array}$ & Moths & 0.833 & 0.372 & $.0302 *$ & & \\
\hline $\operatorname{Rec}$ & 17.5 & $\begin{array}{l}.0001 \\
* * * \\
\end{array}$ & $\operatorname{Rec}$ & 1.120 & 0.268 & $\begin{array}{l}.0001 \\
* * * \\
\end{array}$ & & \\
\hline \multicolumn{7}{|c|}{ Average 2005-2008 } & \multirow{6}{*}{0.554} & \multirow{6}{*}{$55.41 \%$} \\
\hline Regression & 17.4 & $\begin{array}{l}.0000 \\
* * *\end{array}$ & Intercept & 4.470 & 9.351 & $\begin{array}{l}.6345 \\
\mathrm{~ns}\end{array}$ & & \\
\hline lunar dayes & 0.3 & $.6031 \mathrm{~ns}$ & lunar dayes & -0.121 & 0.030 & $\begin{array}{c}.0001 \\
* * *\end{array}$ & & \\
\hline $\begin{array}{l}\text { Percent } \\
\text { LIGHT }\end{array}$ & 2.7 & $.1058 \mathrm{~ns}$ & $\begin{array}{l}\text { Percent } \\
\text { LIGHT }\end{array}$ & 0.151 & 0.175 & $\begin{array}{l}.3914 \\
\mathrm{~ns}\end{array}$ & & \\
\hline Moths & 54.0 & $\begin{array}{l}.0000 \\
* * *\end{array}$ & Moths & 1.023 & 0.392 & $.0116 *$ & & \\
\hline $\operatorname{Rec}$ & 12.6 & $\begin{array}{l}.0008 \\
* * *\end{array}$ & $\operatorname{Rec}$ & 1.136 & 0.320 & $\begin{array}{l}.0008 \\
* * * \\
\end{array}$ & & \\
\hline
\end{tabular}


Table 5. Briefly analysis Varriance of multiple reggression (full model) and Regression equation paramet (larvae ) for four independent variables during 2005 -2008 cotton season

\begin{tabular}{|c|c|c|c|c|c|c|c|c|}
\hline \multicolumn{7}{|c|}{2005} & \multirow{3}{*}{$r^{2}$} & \multirow{3}{*}{$\begin{array}{l}\text { Total effect of } \\
\text { independent } \\
\text { variables }\end{array}$} \\
\hline \multicolumn{3}{|c|}{ Analysis Varriance } & \multicolumn{4}{|c|}{$\begin{array}{l}\text { Regression equation parameters of } \\
\text { predictrd larvae }\end{array}$} & & \\
\hline Source & $\mathrm{F}$ & $\mathrm{P}$ & parameters & Coef. & $\begin{array}{l}\text { Std } \\
\text { Error }\end{array}$ & $P$ & & \\
\hline Regression & 119.1 & .0000 & Intercept & -0.169 & 1.023 & $\begin{array}{l}.8695 \\
\text { ns }\end{array}$ & \multirow{6}{*}{0.939} & \multirow{6}{*}{$93.90 \%$} \\
\hline $\begin{array}{l}\text { lunar } \\
\text { dayes }\end{array}$ & 169.5 & .0000 & lunar dayes & 0.001 & 0.005 & $\begin{array}{l}.9034 \\
\text { ns }\end{array}$ & & \\
\hline $\begin{array}{l}\text { Percent } \\
\text { LIGHT }\end{array}$ & 14.8 & $\begin{array}{l}.0004 \\
* * * \\
\end{array}$ & $\begin{array}{l}\text { Percent } \\
\text { LIGHT }\end{array}$ & -0.006 & 0.005 & $\begin{array}{l}.2663 \\
\mathrm{~ns}\end{array}$ & & \\
\hline Moths & 0.6 & $\begin{array}{c}.4418 \\
\mathrm{~ns}\end{array}$ & Moths & -0.102 & 0.029 & $\begin{array}{l}.0009 \\
* * *\end{array}$ & & \\
\hline EGG & 388.7 & $\begin{array}{l}.0000 \\
* * *\end{array}$ & EGG & 0.492 & 0.025 & .0000 & & \\
\hline $\operatorname{Rec}$ & 22.0 & .0000 & $\operatorname{Rec}$ & 0.122 & 0.026 & .0000 & & \\
\hline \multicolumn{7}{|c|}{2006} & \multirow{7}{*}{0.824} & \multirow{7}{*}{$82.40 \%$} \\
\hline Regression & 36.5 & $\begin{array}{l}.0000 \\
* * *\end{array}$ & Intercept & 6.238 & 2.413 & * 0136 & & \\
\hline $\begin{array}{l}\text { lunar } \\
\text { dayes }\end{array}$ & 36.2 & .0000 & lunar dayes & -0.039 & 0.015 & * 0131 & & \\
\hline $\begin{array}{l}\text { Percent } \\
\text { LIGHT }\end{array}$ & 0.4 & $\begin{array}{l}.5567 \\
\mathrm{~ns}\end{array}$ & $\begin{array}{l}\text { Percent } \\
\text { LIGHT }\end{array}$ & -0.016 & 0.011 & $\begin{array}{l}.1630 \\
\text { ns }\end{array}$ & & \\
\hline Moths & 57.4 & .0000 & Moths & -0.019 & 0.110 & $\begin{array}{l}.8666 \\
\text { ns }\end{array}$ & & \\
\hline EGG & 80.3 & $\begin{array}{l}.0000 \\
* * *\end{array}$ & EGG & 0.397 & 0.042 & .0000 & & \\
\hline $\operatorname{Rec}$ & 8.3 & .0064 & $\operatorname{Rec}$ & 0.210 & 0.073 & $\begin{array}{l}.0064 \\
* *\end{array}$ & & \\
\hline \multicolumn{7}{|c|}{2007} & \multirow{7}{*}{0.840} & \multirow{7}{*}{$84.01 \%$} \\
\hline Regression & 46.6 & .0000 & Intercept & -2.149 & 2.064 & $\begin{array}{l}.3521 \\
\text { ns }\end{array}$ & & \\
\hline $\begin{array}{l}\text { lunar } \\
\text { dayes }\end{array}$ & 37.3 & .0000 & lunar dayes & 0.007 & 0.010 & $\begin{array}{l}.6327 \\
\text { ns }\end{array}$ & & \\
\hline $\begin{array}{l}\text { Percent } \\
\text { LIGHT }\end{array}$ & 0.0 & $\begin{array}{l}.8737 \\
\text { ns }\end{array}$ & $\begin{array}{l}\text { Percent } \\
\text { LIGHT }\end{array}$ & 0.030 & 0.011 & $\begin{array}{l}.0108 \\
*\end{array}$ & & \\
\hline Moths & 67.6 & .0000 & Moths & 0.148 & 0.114 & $\begin{array}{l}.1891 \\
\text { ns }\end{array}$ & & \\
\hline EGG & 122.7 & $\begin{array}{l}.0000 \\
* * *\end{array}$ & EGG & 0.214 & 0.023 & .0000 & & \\
\hline $\operatorname{Rec}$ & 5.5 & .0235 & $\operatorname{Rec}$ & -0.302 & 0.122 & .0235 & & \\
\hline \multicolumn{7}{|c|}{2008} & \multirow{7}{*}{0.833} & \multirow{7}{*}{$83.34 \%$} \\
\hline Regression & 42.0 & .0000 & Intercept & 4.799 & 1.334 & .0008 & & \\
\hline $\begin{array}{l}\text { lunar } \\
\text { dayes }\end{array}$ & 3.2 & $\begin{array}{l}.0787 \\
\text { ns }\end{array}$ & lunar dayes & -0.045 & 0.006 & .0000 & & \\
\hline $\begin{array}{l}\text { Percent } \\
\text { LIGHT }\end{array}$ & 3.0 & $\begin{array}{l}.0900 \\
\text { ns }\end{array}$ & $\begin{array}{l}\text { Percent } \\
\text { LIGHT }\end{array}$ & 0.003 & 0.006 & $\begin{array}{l}.6470 \\
\text { ns }\end{array}$ & & \\
\hline Moths & 51.0 & $\begin{array}{l}.0000 \\
* * *\end{array}$ & Moths & 0.149 & 0.066 & $* 0300$ & & \\
\hline EGG & 5.0 & .0311 & EGG & -0.120 & 0.026 & $\begin{array}{l}.0000 \\
* * *\end{array}$ & & \\
\hline $\operatorname{Rec}$ & 147.8 & $\begin{array}{l}.0000 \\
* * *\end{array}$ & $\operatorname{Rec}$ & 0.650 & 0.053 & $\begin{array}{l}.0000 \\
* * *\end{array}$ & & \\
\hline \multicolumn{7}{|c|}{ Average 2005-2008 } & \multirow{7}{*}{0.949} & \multirow{7}{*}{$94.90 \%$} \\
\hline Regression & 204.0 & $\begin{array}{l}0000 \\
* * *\end{array}$ & Intercept & 2.482 & 1.093 & .0268 & & \\
\hline $\begin{array}{l}\text { lunar } \\
\text { dayes }\end{array}$ & 4.0 & $\begin{array}{l}.0515 \\
\text { ns }\end{array}$ & lunar dayes & 0.003 & 0.004 & $\begin{array}{l}.3896 \\
\text { ns }\end{array}$ & & \\
\hline $\begin{array}{l}\text { Percent } \\
\text { LIGHT }\end{array}$ & 3.1 & $\begin{array}{l}.0850 \\
\mathrm{~ns}\end{array}$ & $\begin{array}{l}\text { Percent } \\
\text { LIGHT }\end{array}$ & -0.060 & 0.021 & .0046 & & \\
\hline Moths & 435.1 & .0000 & Moths & -0.004 & 0.048 & $\begin{array}{l}.9610 \\
\text { ns }\end{array}$ & & \\
\hline EGG & 577.6 & .0000 & EGG & 0.342 & 0.016 & $\begin{array}{l}.0000 \\
* * *\end{array}$ & & \\
\hline $\operatorname{Rec}$ & 0.3 & $\begin{array}{l}.6052 \\
\text { ns }\end{array}$ & $\operatorname{Rec}$ & -0.021 & 0.041 & $\begin{array}{l}.6052 \\
\text { ns }\end{array}$ & & \\
\hline
\end{tabular}



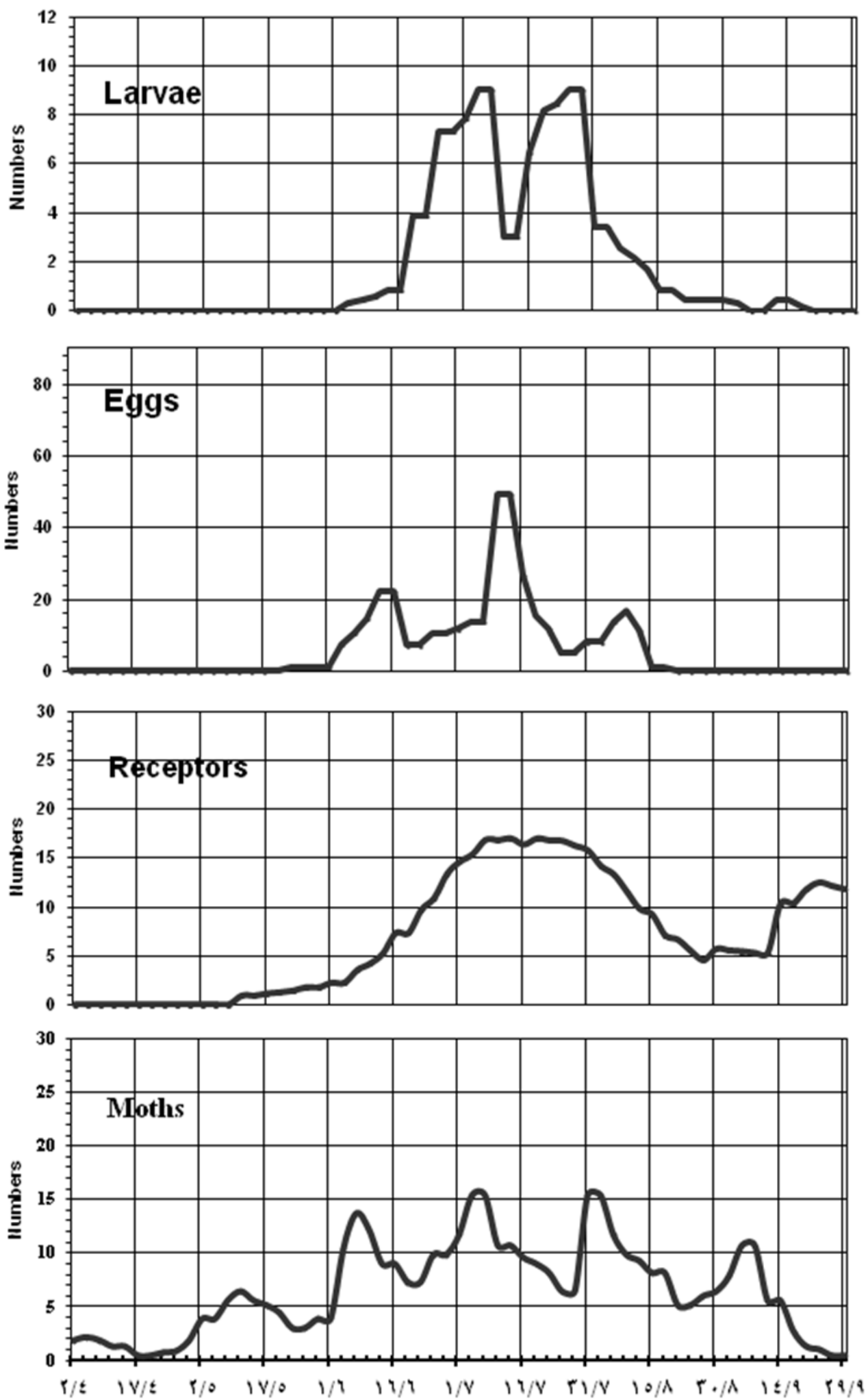

Figure(4): Peaks occurrences of different stages of Helicoverpa armigera , moths, eggs, larvae, and cotton receptors during 2008 cotton season 

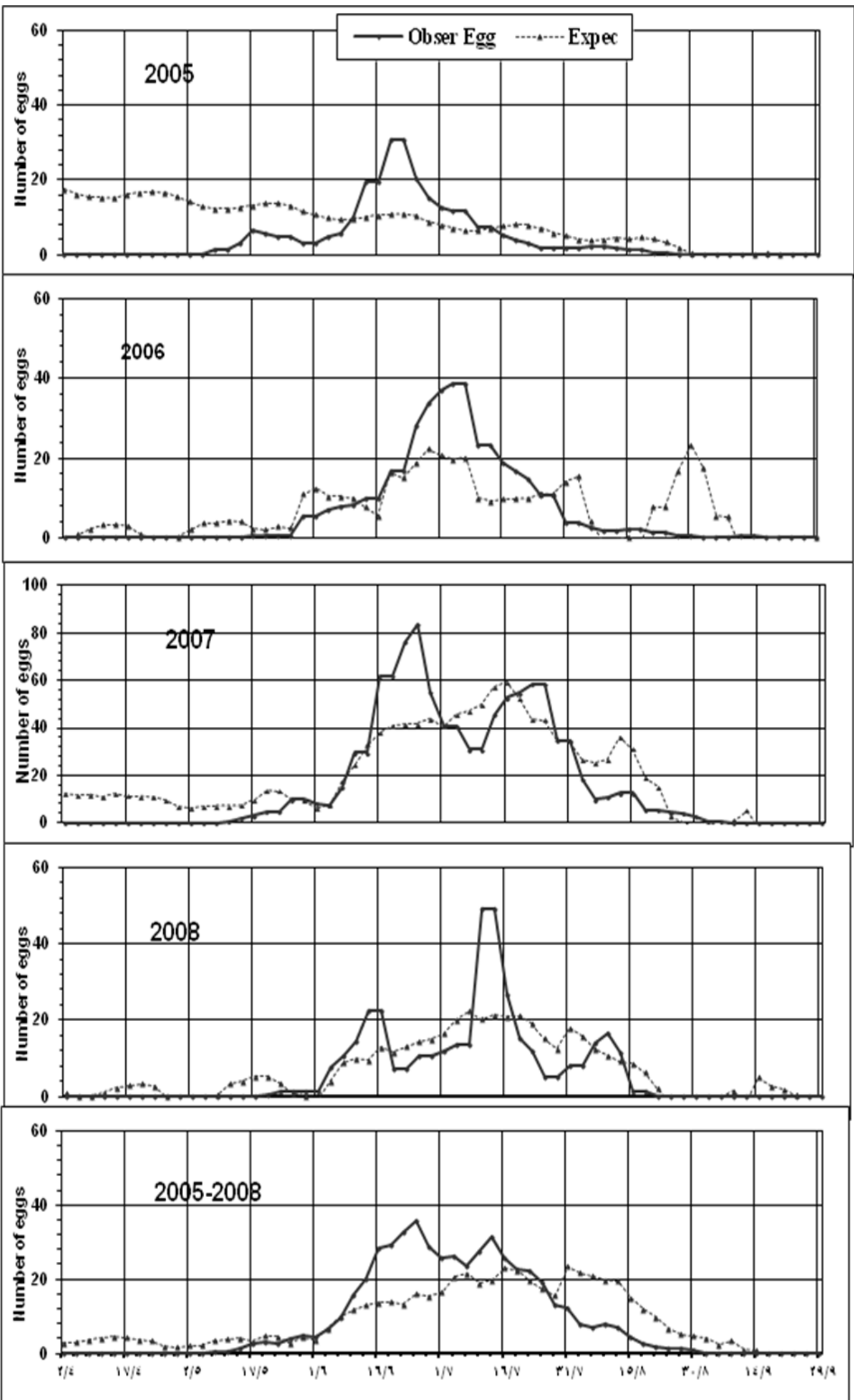

Figure (5): Observed Helicverpa armigera eggs and the predicted dependant variable (eggs) affected by four indep endent variables subjected to the multiple regression (full model) during 2005-2008 cotton seasons 
Table 6. Sum of deviation squares of the expected than observed population of $H$. armigera eggs and larvae

\begin{tabular}{|c|c|c|}
\hline \multirow{2}{*}{ Season } & \multicolumn{2}{|c|}{ summation } \\
\cline { 2 - 3 } & Eggs & Larvae \\
\hline 2005 & 5100.23 & 50.8 \\
\hline 2006 & 3523.37 & 302.7 \\
\hline 2007 & 9285.21 & 204.9 \\
\hline 2008 & 2924.05 & 88.0 \\
\hline average 2005-2008 & 3339.21 & 44.57 \\
\hline
\end{tabular}

\section{REFERENCES}

1. Bilal Saeed Khan, M. Afzal and M. Afzal Murtaza. 2003. Effect of Abiotic Factors Against the infestation of American Bollworm (Heliothis armigera Hub.) on Different Varieties of cotton under Unsprayed Conditions. OnLine Jurnal of Biological Science 3 (1): 82-85, 2003

2. Bowden, J., and B. M. Church. 1973. The influence of moonlight on catches of insects in light traps in Africa. 11: The effect of moon phase on light trap catches, Bull. Ent. Res., 63: 129-142.

3. El-Sayed, A.A.A., Merfat A. Kandil and A.E.A Amer. 2009. Seasonal fluctuation of Helicoverpa armigera (Hubner) (Lepidoptera: Noctuidae) on cotton \& okra and heat units related. Egypt. J. Agric. Res., 87 (4):909-921.

4. Fitt, G. P. 1989. The ecology of Heliothis in relation to agro-ecosystems. Ann. Rev. Ent., 34:17-52.

5. Gomez, K.A. and A. A. Gomez. 1983. Statistical procedures for agricultural research. Hand book (Second edition).Sampling Techniques, 534 P.

6. Hosny, M. M. 1958. Ecological studies on the environment preference and sex ratios in catches of macrolepidoptra in UV- light traps. Bull. Soc. Ent. Egypte', 42:421-37.

7. Ibrahim, M.M., A.G. Metwally, N. H. Nazmy and F.E. Z. Ibrahim. 1994. Studies on the American bollworm on cotton in Egypt Heliothis zea (Boddie), Heliothis armigera (Hb.)(Lepidoptera: Noctuidae). Agric. Res. Rev., 52:1-8.

8. Khalid Zafar, Anjum Suhail, M.Arshad and M.Jalal Arif. 2013. Impact of Weather Factors on population fluctuation of $\mathrm{H}$. armigera on $\mathrm{H}$. armigera on Sunflower.Pakistan Journal of Nutrition 12 (1):50-54, 2013.

9. K uldeep Singh, SVS Raju and DK Singh. 2011. Population Succession of tomato fruit borer (Helicoverpa armigera) on tomato (Lycopersicon esculentum Mill.) agro - ecosystem in eastern region of U.P.Vegetable Science (2011) 38(2):152-155. 
10. Legaspi, B. A., W. L. Sterling, A. W. Hartstack and D. A. Dean. 1989. Testing the interaction of pest-predators-plant components of the Texcim model. Environ. Entomol. 4:157-163.

11. Nada, M. A., M. G. Ragab and E.S. Mansour. 2004. Seasonal abundance and prediction possibility of American bollworm, Helicoverpa armigera (Hüb.) in relation to pheromone trap catches and heat unit accumulations. Egypt.J.Appl.Sci., 19 (11): 394-409.

12. Nada, M. A. M. and M.G. Ragab. 2010. Prediction of American bollworm, Helicoverpa armigera (HÜb.), depending on accumulated heat units in cotton fields. J. Plant Protection and Pathology, 1 (4):195-208.

13. Nada, M.A., M. G. M. Ragab and A.A.A. Zaki. 2012. Relationship between lunar light and population of Helicoverpa armigera (HÜb.) moths at Gharbia Governorate. J. Plant Prot. and Path., Mansoura Unv., 3 (11):1241-1251.

14. Nemec, S. J. 1971. Effect of lunar phases on light trap collection and population of bollworm moths. J. Econ. Ent. 64: 860-64.

15. Ragab, M. G. 2009. Effect of accumulated heat units and cotton fruit structures on larval infestation of Helicoverpa armigera (Hüb.) on cotton and cowpea in different planting systems. Bull. Entomol. Soc. Egypt, 86: 249-265.

16. Ragab, M.G. 2004. Abundance of certain insect pests and associated predators in cotton fields. J. Agric. Sci., Mansoura Univ. 29(1). 6625-6642.

17. Ragab, M. G., H. A. S. Abdel-Gawad and S. N. Kostandy. 2009. The correlation between the predatory insects and the cotton bollworms in untreated cotton fields at Gharbia Governorate. Bull. Ent. Soc. Egypt, 86: 149-160.

18. Sadanny, E.L., A. M. Hossain, R. S. M. El-Fateh and M. A. Romeilah 1999.The Simultaneous effect of physical environmental factors governing the population activity of cotton bollworm moths. Egyptian J. Agric. Res., 77: 591609.

19. Salem, Hoda Abd El-Fattah, M.G. Ragab and Mahasen M.A. El-Shershaby 2004. Monitoring the triangular relationship between maize, cotton and the infestation of the American bollwonn (ABW), Helicoverpa armigera (Hüb.) and the spiny bollworm (SBW), Earias insulana (Boisd.). AI-Azhar J. Agric. Res., 39 : 3 1-35.

20. Youssef, H. L. and H. Ismail. 1999. Phenological synchronism for Spodoptera littorals (Boisd.) life cycle (Lep.-Noct.). Ann. of Agric., 37:2049-2057.

21. Zalucki, M. P., D.A. H. Murray, P. C. Grgg, G. P. Fitt, P. H. Twine and C. Jones. 1994. Ecological of Helicoverpa armigera ( $\mathrm{Hb}$.$) and H$. punctigera (Vallengren) in the land of Australia : Larval sampling and host relationships during winter and spring. Aust. J. Zool., 42: 329-333. 
تأثير بعض العو امل البيئية الحيوية وغير الحيوية علي التقلبات الموسمية لاودة اللوز الأمريكية (هيليكوفيربا أرميجرا ( هوينر)) محمد جمعه رجب، على أحمد أحمد ألسيد و محمد أحمد ندا معهد بحوث وقاية النباتات- مركز البحوث الزرراعية- دقى جيزة

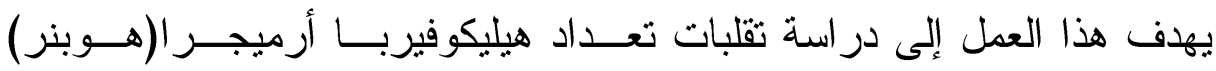
الموسمية وعلاقة تعداد البيض واليرقات بعض العوامل الحيوية وغير الحيوية. تــــ

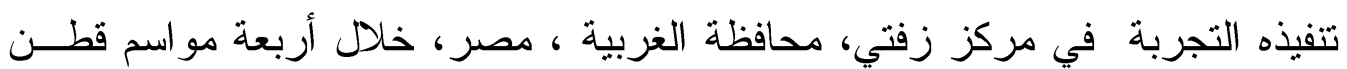

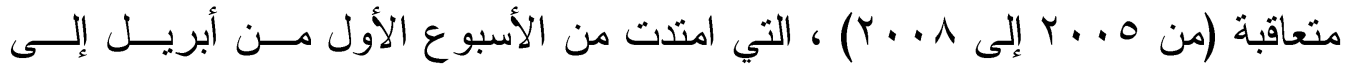

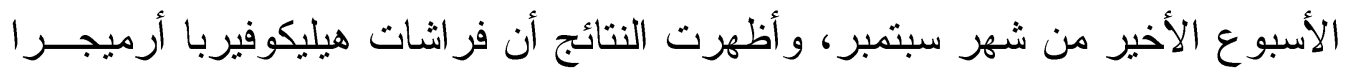

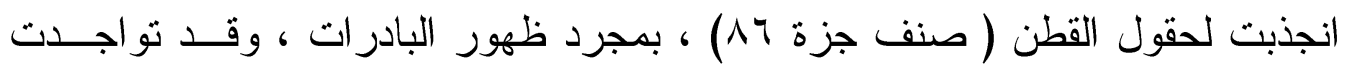

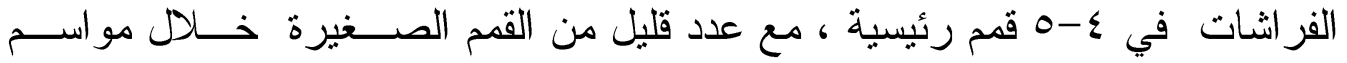
الدراسة ، بدأت تر اكيب القطن الثمرية (المستقبلات) في الظهور في النصــف الأول من مايو واستمرت حتى نهاية فترة الدراسة. و إحصائيا وجد من واحد إلى ثلاث قمم رئيسية لبيض ويرقات هيليكوفيربا أرميجير أثناء فترات الدراسة، ولئه ، ولتوقع المتغيرين

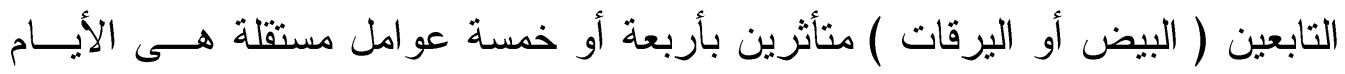

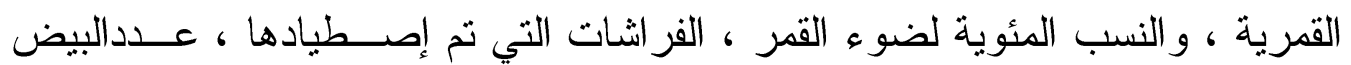

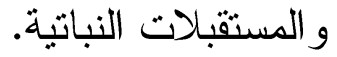
تم تطبيق الانحدار المتعدد (النموذج الكامل) على هذه المتغيرات خلال مواسم

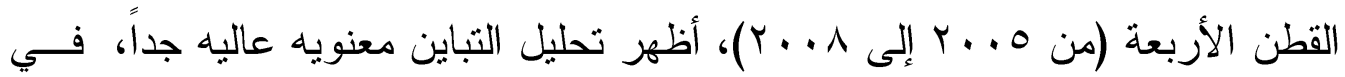

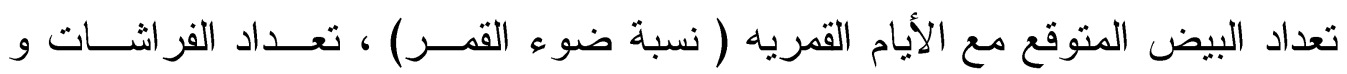

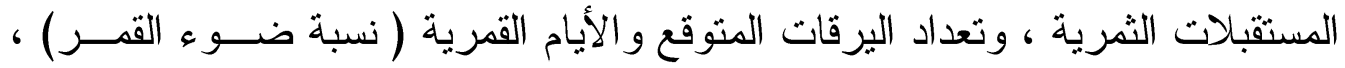

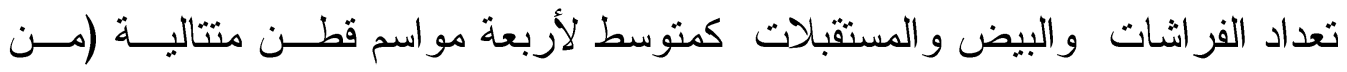

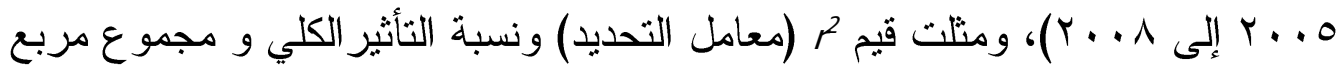

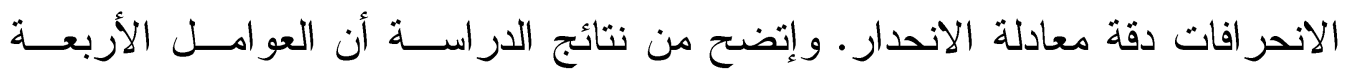

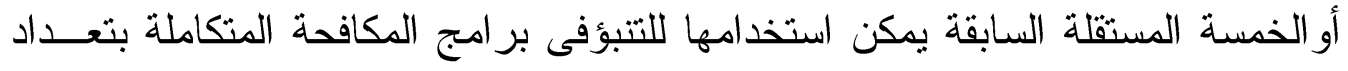
بيض أو يرقات هيليكوفيربا أرميجير ا قبل بلوغها مستويات الذروة على نباتات القطن 